\title{
Main and Interaction Effects of Factors on Softwood Cutting of White Poplar (Populus alba L.).
}

\author{
By A. Harfouche ${ }^{1,2)}$, N. Baoune ${ }^{1)}$ and H. MerazGA ${ }^{1)}$
}

(Received 30 $0^{\text {th }}$ August 2006)

\begin{abstract}
White poplar is an important species for reforesting riparian sites in Algeria, but efficient techniques are still to be perfected. The study investigates the feasibility of softwood cutting as a method of propagation of the species. Results showed that sand or gravel, used as substrate, do not determine significant differences in rooting percent, but exert an influence on the quality and vigour of roots of cuttings. The findings, also, suggest that softwood cutting of the species would be most efficient if root suckers and/or sticklings were the sources of cuttings. Moreover, summer is the best period for achieving good results, while IBA treatments would have little effect on the rooting response of cuttings. Significant stand and individual within stand variation in rooting response of cuttings was found. However, the low or moderate broad sense heritabilities suggest that microsite effects at the individual scale could influence significantly the results. Overall, the results of the investigations suggest that selection of stands and, individuals within stands with good rooting ability, together with taking care with respect to factors such as the period of cuttings collection and the sources of cuttings, could achieve real progress in vegetative propagation of white poplar in Algeria.
\end{abstract}

Key words: white poplar, softwood cutting, rooting ability.

\section{Introduction}

Poplars are species of paramount importance for wood market, providing an important amount of ligneous matter per unit of time thanks to their fast growing potential. These trees, whose wood benefits of various outlets, have since long aroused the interest of foresters and constitute nowadays an important piece of what is called the clonal forestry. Poplar culture is now generally quite intensive resembling in that to agricultural crops. Poplars culture, in order to make a better investment of techniques, had to use genetic material highly selected for criteria of growth, form and wood quality. Then, perfecting methods of propagation is necessary, both fast and economical, capable to get the most profit of the genetic progress of that selection. Cutting was and remains one of the most successful techniques to reproduce intensive timber production species (CHAPERON and QUILLET, 1977; RICHARDSON, 1998; HAAPALA, 2004).

However, mass propagation of genotypes is not always easy due to the poor rooting ability of stem cuttings in

\footnotetext{
1) Institut National de Recherche Forestière, Arboretum de Baïnem, B. P. 37 CHERGA, Alger, Algérie.

2) Author to whom correspondence must be addressed.

E-mail: gene@inrf.rg.dz; a_harfouche@yahoo.fr; a_harfouche@hotmail.com.
}

some poplar species of the section Leuce including white poplar (WRIGHT, 1976; ABDELDAYEM, 2000).

Dormant cutting is currently the sole technique used to propagate white poplar in Algeria (BESSAFA, 1991); this technique, however, does not allow a high multiplication rate because of the large size of cuttings and containers. Vegetative propagation of white poplar by softwood cutting could be a good alternative. Meanwhile, information is rare on factors influencing rooting ability of softwood cuttings of white poplar, especially, at the local scale. Rooting ability of cuttings in woody plants is markedly influenced by several factors including e.g. the genotype (HUSEN, 2004), the position of cuttings on the tree donor (HARTMANN et al., 1997; HUSEN and PAL, 2003c), the period of collection (FAVREAU, 1980; THOMPSON, 1992) and the media of culture (FAVREAU, 1980; RAUTER, 1983).

In the present work, trials were carried out to study (1) the main effects of factors, physical and biological, related to the plant material and environment and the medium of culture, and (2) the interaction effects between these factors.

\section{Material and Methods \\ Plant materials}

The plant materials used in this work has been collected on adult (30-years old) white poplars from four riparian natural stands in the region of Algiers $\left(36^{\circ} 48^{\prime} \mathrm{N}\right.$; $\left.3^{\circ} 4^{\prime} \mathrm{E}\right)$, growing in locations around $10 \mathrm{~km}$ apart in distinct valleys. In January, a sub-sample of donor plants were cut $40 \mathrm{~cm}$ above the ground in order to obtain coppice shoots. Then, three sources of cutting material from natural stands were used (1) root suckers, (2), reiteration shoots (produced following a break of a branch), and (3) stump sprouts from cut trees.

Softwood and/or semi-hardwood shoots were collected in spring, summer and autumn according to the experimental plans and factors to be studied. Collected shoots were immediately (in situ) soaked for a few seconds in a fungicidal solution with $1 \mathrm{~g} / \mathrm{l}$ of Benlate and then transported in cool boxes onto the workplace. There, shoots were cut up to cuttings $10-15 \mathrm{~cm}$ long, and size of leaves, when too expanded, reduced by half in order to avoid their early fall by gravity. The base of cuttings were treated with a growth regulator when planned. Cuttings were then stuck into the final container.

\section{Environment of culture}

The greenhouse where trials were conducted is situated at the Experimental Station of Baïnem, 8-kms west to Algiers $\left(36^{\circ} 47^{\prime} \mathrm{N}, 3^{\circ} 4^{\prime} \mathrm{E}\right)$. The climate is mediter- 
Table 1. - Extreme and average temperatures (Degrees Celsius) outside the greenhouse (Reference station $5 \mathrm{kms}$ apart, $36^{\circ} 48^{\prime} \mathrm{N}, 3^{\circ} 1^{\prime} \mathrm{E}$ ).

\begin{tabular}{lccccccc}
\hline Month & $\mathbf{m} \mathbf{y}^{\prime}$ & $\mathbf{m}$ & $\mathbf{m}$ & $\mathbf{( m + \mathbf { M } ) / \mathbf { 2 }}$ & $\mathbf{M}$ & $\mathbf{M}$ & M'" \\
\hline January & -0.1 & 3.4 & 7.8 & 10.05 & 12.3 & 17.2 & 22.2 \\
February & 0.2 & 3.4 & 8.0 & 10.65 & 13.3 & 19.6 & 27.9 \\
March & 0.1 & 4.4 & 9.0 & 11.95 & 14.9 & 22.2 & 26.4 \\
April & 3.7 & 6.4 & 10.8 & 14.10 & 17.4 & 26.3 & 34.1 \\
May & 4.9 & 9.5 & 13.6 & 17.05 & 20.5 & 29.8 & 37.2 \\
June & 10.4 & 13.8 & 16.9 & 20.35 & 23.8 & 32.0 & 36.3 \\
July & 14.7 & 16.7 & 19.8 & 23.55 & 27.3 & 36.3 & 42.9 \\
August & 15.5 & 17.5 & 20.6 & 24.30 & 28.0 & 36.5 & 42.9 \\
September & 10.4 & 14.3 & 18.9 & 22.25 & 25.6 & 33.4 & 40.1 \\
October & 5.0 & 10.2 & 15.4 & 18.30 & 21.2 & 28.5 & 35.2 \\
November & 1.8 & 8.5 & 11.5 & 14.05 & 16.6 & 23.5 & 28.9 \\
Decembre & -2.2 & 3.1 & 8.6 & 10.90 & 13.2 & 18.7 & 23.5 \\
\hline Year & $\mathbf{- 2 . 2}$ & $\mathbf{9 . 1}$ & $\mathbf{1 3 . 4}$ & $\mathbf{1 6 . 4 5}$ & $\mathbf{1 9 . 5}$ & $\mathbf{2 7 . 0}$ & $\mathbf{4 2 . 9}$ \\
\hline
\end{tabular}

Temperatures were about $5^{\circ} \mathrm{C}$ lesser inside than outside the greenhouse. m": the absolute minimum ever recorded, m': the raw average of monthly extreme minima, $\mathrm{m}$ : the average of all the minima, $(\mathrm{m}+\mathrm{M}) / 2$ : the monthly average temperature, M: the average of all the minima, M': the raw average of monthly extreme maxima, M": the absolute maximum ever recorded (After Seltzer, 1946: Le climat de l'Algérie).

ranean subhumid, with January and August the coldest and warmest months, respectively (see Table 1 for extreme and average temperatures). In summer, temperatures inside were about $5^{\circ} \mathrm{C}$ down temperatures outside the greenhouse, thanks to an intermittent mist and openings. Light energy intensity inside the greenhouse may vary from 100 to $400 \mathrm{~W} / \mathrm{m}^{2}$, depending on nebulosity.

Cuttings were raised into individual plastic containers on propagation beds in a greenhouse entirely covered with plastic sheets and equipped with a mist system which allowed to maintain a high relative humidity around the cuttings. Before experiments were implemented, containers, substrates of culture and the ground in the greenhouse were treated with a Manebe-2 $\mathrm{g} / \mathrm{l}$ fungicidal solution; in the course of the experiments, cuttings were treated with a Benlate- $1 \mathrm{~g} / \mathrm{l}$ solution.

To limit extra influences (Shadow, edge effects, etc.), cuttings have been arranged randomly in complete blocks (Complete repetitions of planned treatments).

\section{Experimental factors studied and trials}

Several trials were carried out for studying the following factors:

The type of substrate. Two types of substrate were tested: (1) inert fine $(\varnothing \approx 2 \mathrm{~mm})$ river sand, and (2) inert fine gravel $(\varnothing \approx 3-5 \mathrm{~mm})$. Both were washed and sterilised in a solution with commercial bleach and Benlate ( $1 \mathrm{~g} / \mathrm{l})$. Hundred fifty cuttings were used per substrate.

The source of cuttings. Four sources of cuttings were tested: (1) root suckers, (2) stump sprouts, (3) reiteration shoots, and (4) stecklings (one year old, container stock). Stecklings originated from the same individuals and stands as the other plant materials. Hundred cuttings were used per source.

Hormonal treatment. The synthetic auxin indole-3butyric acid (IBA) was the hormone used for our experiments. IBA was applied in talcum powder formulations of $0.00 \%$, (control without IBA), $0.10 \%, 0.15 \%, 0.20 \%$ and $0.60 \%$. Eighty cuttings were used per treatment.

The period of cutting. Cutting was made in spring, summer and autumn. Due to the lack of stump sprouts in spring, only root suckers, reiteration shoots and stecklings were used in this trial. Hundred cuttings were used for each period.

Stand and individual within stand. Four natural stands were included in the trial, with five individuals representing each stand. For this trial, cuttings came exclusively from root suckers at a rate of 30 cuttings per individual, and so 150 per stand.

\section{Statistical analyses}

For testing frequencies (\% of rooting), homogeneity tests of Khi-square were used:

$$
\chi^{2}=\sum \frac{\left(f_{o}-f_{e}\right)^{2}}{f_{e}}
$$

where $f_{o}$ is the observed frequency of rooting and $f_{e}$ the expected frequency.

Variation of quantitative traits (number of roots/cutting and length of the main root/cutting) was analysed by ANOVA models as follows:

$$
\begin{aligned}
X i j k l= & \mu+s b_{i}+s r_{j}+h t k+\left(s b^{*} s r\right)_{i j}+\left(s b^{*} h t\right)_{i k} \\
& +\left(s r^{*} h t\right)_{j k}+\left(s b^{*} s r^{*} h t\right)_{i j k}+e_{i j k l}
\end{aligned}
$$

and,

$$
\begin{aligned}
X i j k l= & \mu+p e_{i}+s r_{j}+h t k+\left(p e^{*} s r\right)_{i j}+\left(p e^{*} h t\right)_{i k} \\
& +\left(s r^{*} h t\right)_{j k}+\left(p e^{*} s r^{*} h t\right)_{i j k}+e_{i j k l}
\end{aligned}
$$

where $X_{i j k l}$ is the score or the measure of the $l^{\text {th }}$ cutting, $\mu$ is the general mean, $s b_{i}$ is the fixed effect of the $i^{t h}$ substrate, $p e_{i}$ is the fixed effect of the $i^{t h}$ period, $s r_{j}$ is the fixed effect of the $j^{\text {th }}$ source of cuttings, $h t_{k}$ the random effect of the $k^{\text {th }}$ hormonal treatment; between parentheses are the interactions between these main effects, and $e_{i j k l}$ is the random error. 
All number of roots/cutting data were transformed to square root to improve normality and homogenize variance.

For stand and individual within stand analysis of variance, a hierarchical model was developed as follows:

$$
X_{i j}=\mu+S_{i}+(I / S) i_{j}+e_{i j k}
$$

for analysis across all stands, and:

$$
X_{i j}=\mu+I_{i}+e_{i j}
$$

for analysis of each (clone) individual separately.

In model [4], $\mu$ is the grand mean, $S_{i}$ is the random effect of the $i^{t h}$ stand, $(I / S)_{i j}$ is the effect of the $j^{\text {th }}$ clone within the $i^{t h}$ stand, and $e_{i j k}$ is the random error (residual effect).

In model [5], $\mu$ is the grand mean, $I_{i}$ is the effect of the $i^{\text {th }}$ clone, and $e_{i j}$ is the random error.

Following model [4], repeatability was defined globally at the stand and individual/stand levels simultaneously as follows:

$$
\begin{aligned}
& h_{S+I / S}^{2}=\frac{\operatorname{cov}\left(X_{i j k}, X_{i j k^{\prime}}\right)}{\operatorname{var}\left(X_{i j k}\right)}=\frac{\operatorname{cov}\left(\mu+S_{i}+(I / S)_{i j}+e_{i j k}, \mu+S_{i}+(I / S)_{i j}+e_{i j k^{\prime}}\right)}{\operatorname{var}\left(\mu+S_{i}+(I / S)_{i i}+e_{i j k}\right)} \\
& h_{S+I / S}^{2}=\frac{\sigma_{S}^{2}+\sigma_{I / S}^{2}}{\sigma_{S}^{2}+\sigma_{I / S}^{2}+\sigma_{e}^{2}}
\end{aligned}
$$

since $\sigma_{\mu}^{2}=0$, and $\operatorname{cov}\left(e_{i j k}, e_{i j k}\right)=0$, the residual effects $e_{i j k}$ and $e_{i j k}$, being assumed to be independent.

From model [5] were derived the clone heritabilities in each stand:

$$
\begin{aligned}
& h_{I}^{2}=\frac{\operatorname{cov}\left(X_{i j}, X_{i j^{\prime}}\right)}{\operatorname{var}\left(X_{i j}\right)}=\frac{\operatorname{cov}\left(\mu+I i+e_{i j}, \mu+I_{i}+e_{i j^{\prime}}\right)}{\operatorname{var}\left(\mu+I_{i}+e_{i j}\right)}=\frac{\sigma_{\mu}^{2}+\sigma_{I}^{2}+\operatorname{cov}\left(e_{i j, e i i^{\prime}}\right)}{\sigma_{\mu}^{2}+\sigma_{I}^{2}+\sigma_{e}^{2}} \\
& h_{I}^{2}=\frac{\sigma_{I}^{2}}{\sigma_{I}^{2}+\sigma_{e}^{2}}
\end{aligned}
$$

The interest of these two parameters is obvious for selection; the first one is useful for selecting among stands, and the second among clones in each stand

Analyses of variance were performed using STATISTICA program version 6.0. Before final analysis, raw data have been adjusted to block effects using adequate models.

\section{Results}

\section{Effect of substrate}

Non significant difference was observed as regards the percentage of rooting $(77.3 \%$ for sand vs $80.0 \%$, for gravel) at $p<0.05$ level (Table 2). On the other hand, significantly more roots per cutting were produced on gravel (16.3) than on sand (11.5), as well as roots were drastically longer on gravel $(114.4 \mathrm{~mm})$ than on sand (46.7 mm) (Table 1).

\section{Effect of the source of cuttings}

The source of cuttings had a significant effect on the percentage of rooting and the number of roots per cutting at 0.05 probability level, but not on the length of the main root (Table 2 ).
Cuttings taken from root suckers showed the highest rooting percentage $(97 \%)$ and number of roots per cutting (33.9) followed by cuttings from sticklings, with $96 \%$ rooting and 22.4 roots per cutting. Cuttings from stump sprouts also displayed a high rooting ability with $91 \%$ of rooted cuttings, but a relatively moderate number of roots per cutting, while those from reiteration shoots revealed to be the less responsive with $86 \%$ rooting and 8.6 roots per cutting.

\section{Effect of the period of collection}

The period of cutting represented a significant source of variation at $p<0.05$ level for percentage of rooting, number of roots per cutting and length of the main root (Table 2). Summer revealed to be the most favourable period for softwood cutting of white poplar. Cutting in summer allowed to reach $96 \%$ of rooted cuttings, while only $55 \%$ and $33 \%$ of cuttings rooted in autumn and spring, respectively. (Table 2). Cuttings initiated more roots in summer (22.4 roots/cutting) than in spring (14.7 roots/cutting) and autumn (6.8 roots/cutting), and developed longer roots in summer $(2.28 \mathrm{~mm} /$ day increment) than in spring ( $1.54 \mathrm{~mm} /$ day increment).

\section{Effect of hormonal treatment}

Except for the number of roots per cutting, there was no significant differences or superiority of IBA treatments over the control at $p<0.05$ regarding the percent rooting and the length of roots (Table 2). For the number of roots per cutting, the highest response was achieved with the treatment $0.60 \%$ IBA (17.3 roots/cutting) followed by the $0.20 \%$ treatment (15.2 roots/cutting). The control $(0.00 \%$ IBA) was the one with the lowest number of roots per cutting (Table 2 ).

\section{Interaction effects}

Results for interaction effects are given in Table 3. The combined effect of substrate and source of cuttings was not significant at $p<0.05$ level for the percentage of rooting $\left(\chi^{2}=0.50 ; p=0.48\right)$, the number of roots/cutting $(\mathrm{F}=0.38 ; p=0.53)$ and the length of the main root $(\mathrm{F}=7.81 ; p=0.22)$.

Interaction effect between substrate and IBA treatments also revealed to be non significant at $p<0.05$ level, as well for the percentage of rooting $\left(\chi^{2}=3.01\right.$; $p=0.55)$ as for the number of roots/cutting $(\mathrm{F}=1.04$; $p=0.39)$ and the length of the main $\operatorname{root}(\mathrm{F}=0.45$; $p=0.77$ ).

The interaction effect between source of cuttings and IBA treatments was a significant source of variation at $p<0.05$ level for the number of roots/cutting $(\mathrm{F}=3.10$; $p=0.02$ ). While the $0.20 \%$ treatment induced the highest number of roots per cutting in root suckers, the $0.60 \%$ treatment revealed to be more efficient in reiteration shoots. This interaction effect was not significant at $p<0.05$ level for the percentage of rooting $\left(\chi^{2}=0.44\right.$; $p=0.97)$ and for the length of the main $\operatorname{root}(\mathrm{F}=2.37$; $p=0.31$ ).

The period of cuttings collection and source of cuttings interact significantly at $p<0.05$ level for the percentage of rooting $\left(\chi^{2}=23.70 ; p<0.0001\right)$ and the number of 
roots/cutting $(\mathrm{F}=14.44 ; p=0.0002)$. Root suckers presented the highest percent rooting for spring cutting, while reiteration shoots were more responsive for autumn cutting. The same trend was observed for the number of roots/cutting, i.e. root suckers were superior and reiteration shoots inferior for spring cutting, and vice versa for the autumn cutting. Data were not available for the length of the main root.

The period of cutting interacted significantly with IBA treatments at $p<0.05$ level for the number of roots per cutting $(\mathrm{F}=4.50 ; p=0.002)$, but not for the percentage of rooting $\left(\chi^{2}=3.96 ; p=0.41\right)$ and the length of main

Table 2. - Percentages and Khi-square tests, means and F-tests for main effects of rooting factors.

\begin{tabular}{|c|c|c|c|c|c|c|c|c|c|c|}
\hline \multirow[b]{2}{*}{ Factor } & \multicolumn{3}{|c|}{ of rooting } & \multicolumn{3}{|c|}{$\begin{array}{l}\text { Number } \\
\text { of roots/cutting }\end{array}$} & \multicolumn{3}{|c|}{$\begin{array}{l}\text { Length }(\mathrm{mm}) \\
\text { of the main root }\end{array}$} & \multirow[t]{2}{*}{$\mathrm{N}$} \\
\hline & $\%$ & $\chi^{2}$ & $p$ & mean & $\mathrm{F}$ & $p$ & mean & $\mathrm{F}$ & $p$ & \\
\hline Substrate & & 0.00 & 0.96 & & 4.17 & 0.04 & & 118.9 & $<10^{-6}$ & 300 \\
\hline Sand & 77.3 & & & 11.5 & & & 46.7 & & & 150 \\
\hline Gravel & 80.0 & & & 16.3 & & & 114.4 & & & 150 \\
\hline Source of cuttings & & 11.1 & 0.01 & & 31.20 & $<10^{-6}$ & & 4.11 & 0.10 & 400 \\
\hline Root suckers & 97 & & & 33.9 & & & 86 & & & 100 \\
\hline Sticklings & 96 & & & 22.4 & & & 82 & & & 100 \\
\hline Stump sprouts & 91 & & & 13.1 & & & 1 & & & 100 \\
\hline Reiteration shoots & 86 & & & 8.6 & & & 132 & & & 100 \\
\hline Hormonal treatment & & 4.34 & 0.36 & & 2.53 & 0.04 & & 0.88 & 0.48 & 300 \\
\hline Control $(0 \%)$ IBA & 70 & & & 10.9 & & & 76.4 & & & 60 \\
\hline $0.10 \% \mathrm{IBA}$ & 78 & & & 14.0 & & & 89.2 & & & 60 \\
\hline $0.15 \%$ IBA & 85 & & & 11.9 & & & 73.3 & & & 60 \\
\hline $0.20 \%$ IBA & 75 & & & 15.2 & & & 93.7 & & & 60 \\
\hline $0.60 \%$ IBA & 80 & & & 17.3 & & & 82.6 & & & 60 \\
\hline Period of cutting & & 87.7 & $<10^{-4}$ & & 32.65 & $<10^{-6}$ & & 9.35 & 0.003 & 300 \\
\hline Spring & 33 & & & 14.7 & & & $1.54^{*}$ & & & 100 \\
\hline Summer & 96 & & & 22.4 & & & $2.28^{*}$ & & & 100 \\
\hline Autumn & 51 & & & 6.8 & & & 1 & & & 100 \\
\hline Stand & & 32.19 & $<10^{-4}$ & & 3.35 & 0.04 & & 4.8 & 0.01 & \\
\hline Individual/stand & & 147.12 & $<10^{-4}$ & & 9.76 & $<10^{-6}$ & & 8.3 & $<10^{-6}$ & \\
\hline Stand 1 & 80.0 & 59.17 & $<10^{-4}$ & 14.2 & 8.35 & $6.10^{-6}$ & 27.8 & 4.99 & 0.0009 & 150 \\
\hline Individual 1 & 30.0 & & & 3.4 & & & 4.8 & & & 30 \\
\hline Individual 2 & 93.3 & & & 13.6 & & & 32.7 & & & 30 \\
\hline Individual 3 & 90.0 & & & 7.8 & & & 24.7 & & & 30 \\
\hline Individual 4 & 90.0 & & & 22.7 & & & 29.9 & & & 30 \\
\hline Individual 5 & 96.7 & & & 16.0 & & & 31.1 & & & 30 \\
\hline Stand 2 & 96.7 & 6.20 & 0.18 & 19.1 & 19.34 & $<10^{-6}$ & 43.5 & 15.96 & $<10^{-6}$ & 150 \\
\hline Individual 6 & 100 & & & 26.7 & & & 47.2 & & & 30 \\
\hline Individual 7 & 100 & & & 28.4 & & & 67.6 & & & 30 \\
\hline Individual 8 & 96.7 & & & 16.1 & & & 49.9 & & & 30 \\
\hline Individual 9 & 90.0 & & & 9.1 & & & 22.2 & & & 30 \\
\hline Individual 10 & 96.7 & & & 13.9 & & & 28.1 & & & 30 \\
\hline Stand 3 & 78.0 & 6.45 & 0.17 & 8.0 & 5.82 & 0.0003 & 49.2 & 7.49 & $22.10^{-6}$ & 150 \\
\hline Individual 11 & 73.3 & & & 5.8 & & & $47.0^{\circ}$ & & & 30 \\
\hline Individual 12 & 86.7 & & & 12.1 & & & 38.1 & & & 30 \\
\hline Individual 13 & 70.0 & & & 5 & & & 29.8 & & & 30 \\
\hline Individual 14 & 90.0 & & & 9.2 & & & 72.5 & & & 30 \\
\hline Individual 15 & 70.0 & & & 6.7 & & & 54.6 & & & 30 \\
\hline Stand 4 & 92.0 & 34.06 & $<10^{-4}$ & 11.5 & $4.40^{\circ}$ & 0.002 & $63.4^{-}$ & 5.22 & 0.0006 & 150 \\
\hline Individual 16 & 66.7 & & & 8.4 & & & 52.2 & & & 30 \\
\hline Individual 17 & 100 & & & 11.2 & & & 76.2 & & & 30 \\
\hline Individual 18 & 100 & & & 12.5 & & & 56.5 & & & 30 \\
\hline Individual 19 & 100 & & & 8.4 & & & 52.2 & & & 30 \\
\hline Individual 20 & 93.3 & & & 16.3 & & & 77.5 & & & 30 \\
\hline
\end{tabular}

$\mathrm{N}$ = number of cuttings/class; Individuals 1-20 are cutting donors ( 5 individuals per stand); F-tests for the number of roots/cutting was performed on data transformed to square root; * mm/day. In bold, are significant tests. 
Table 3. - Percents and Khi-square tests, means and F-tests for main effects of rooting factors.

\begin{tabular}{lccccccc}
\hline & & \multicolumn{3}{c}{$\begin{array}{c}\text { \%of } \\
\text { rooting }\end{array}$} & \multicolumn{2}{c}{$\begin{array}{c}\text { Number } \\
\text { of roots/cutting }\end{array}$} & \multicolumn{2}{c}{$\begin{array}{c}\text { Length (mm) } \\
\text { of the main root }\end{array}$} \\
\cline { 3 - 8 } Interaction effects & Df & $\chi^{2}$ & $p$ & $F$ & $p$ & F & $p$ \\
\hline Substrate x source of cutting & 3 & 0.50 & 0.48 & 0.38 & 0.53 & 7.81 & 0.22 \\
Substrate x IBA treatment & 4 & 3.01 & 0.55 & 1.04 & 0.39 & 0.45 & 0.77 \\
Source of cut. x IBA treatment & 12 & 0.44 & 0.97 & $\mathbf{3 . 1 0}$ & $\mathbf{0 . 0 2}$ & 2.37 & 0.31 \\
Period x Source of cutting & 4 & $\mathbf{2 3 . 7 0}$ & $<\mathbf{0 . 0 0 0 1}$ & $\mathbf{1 4 . 4 4}$ & $\mathbf{0 . 0 0 0 2}$ & $/$ & $/$ \\
Period x IBA treatment & 8 & 3.96 & 0.41 & $\mathbf{4 . 5 0}$ & $\mathbf{0 . 0 0 2}$ & 0.01 & 0.99 \\
Substrate x source x hormonal treatment & 12 & $0.47^{*}$ & 0.87 & 0.57 & 0.68 & $\mathbf{0 . 2 9}$ & 0.59 \\
Period x source x hormonal treatment & 16 & $0.61^{*}$ & 0.65 & 0.71 & 0.49 & $/$ & $/$ \\
\hline
\end{tabular}

* Statistical significance of three factors interaction effects was made by analysis of variance on scores data ( 1 for rooting and 0 for non-rooting cuttings). In bold, are significant tests. Df: degrees of freedom.

Table 4. - Components of variance, repeatabilities and heritabilities at a global level (Stand + Individual/Stand) and at the Individual/Stand level.

\begin{tabular}{|c|c|c|c|c|c|c|c|c|c|c|}
\hline & \multicolumn{5}{|c|}{ Number of roots/cutting } & \multicolumn{5}{|c|}{ Length of the main root } \\
\hline & Global & Stand & Stand & Stand & Stand & Global & Stand & Stand & Stand & Stand \\
\hline & & 1 & 2 & 3 & 4 & & 1 & 2 & 3 & 4 \\
\hline$\sigma_{S}^{2}$ & 0.27 & ' & 1 & ' & / & 171.22 & I & I & / & I \\
\hline $\boldsymbol{\sigma}_{I / S}^{2}$ & 0.50 & 0.68 & 0.92 & 0.19 & 0.16 & 189.68 & 52.51 & 308.12 & 246.70 & 133.52 \\
\hline$\sigma_{e}^{2}$ & 1.47 & 2.16 & 1.44 & 0.93 & 1.34 & 667.45 & 307.85 & 597.15 & 885.93 & 868.39 \\
\hline$h_{S+I / S}^{2} / h_{I}^{2}$ & 0.34 & 0.24 & 0.39 & 0.17 & 0.11 & 0.35 & 0.14 & 0.34 & 0.22 & 0.13 \\
\hline
\end{tabular}

$\sigma_{S}^{2}$ is the stand component of variance, $\sigma_{I / S}^{2}$ is the individual within stand component of variance, $\sigma_{e}^{2}$ is the error component of variance, $h_{S+I / S}^{2}$ is the repeatability and $h_{I}^{2}$ is the individual heritability. Note the low or moderate values of repeatabilities and heritabilities, theoretically varying from 0 to 1 .

$\operatorname{root}(\mathrm{F}=0.01 ; p=0.99)$. For the former descriptor, the $0.15 \%$ and $0.20 \%$ treatments were more efficient for spring cutting, and the $0.60 \%$ treatment for the autumn cutting.

Three factors interaction effects were not significant (Table 3).

\section{Effect of stand and individual within stand}

The effect of stand was significant at $p<0.05$ level for percentage of rooting, the number of roots per cutting and the length of main root, as shown in Table 2. Percentage of rooting varied from $78.0 \%$ in one stand to $96.7 \%$ in an other stand; maximum number of roots per cutting was 19.1 and minimum 8.0; main root length distributed from $27.8 \mathrm{~mm}$ to $63.4 \mathrm{~mm}$ (Table 2).

Globally (including the four stands), significant variation among individual/stand was recorded for the percentage of rooting, the number of roots/cutting and the length of main root (Table 2). Percentage of rooting variation between individuals, however, was greater in stand 1 and stand 4 than in stand 2 and stand 3 , as attested by the p-values of khi-squares (Table 2). Variation among individuals for the number of roots/cutting was significant in all the stands, above all in stand 2 (Table 2). Also, the length of main root varied significantly among individuals in all the four stands, but it was particularly high in stand 2 where the $p$-value of $\mathrm{F}$ was lower than $10^{-6}$ (Table 2).

Repeatabilities were just moderate at the global level, $h^{2}=0.34$, for the number of roots/cutting, $h^{2}=0.35$, for the length of the main root (Table 4). In stands taken individually, broad sense heritability was low in stand 4 $\left(h^{2}=0.11\right)$ and stand $3\left(h^{2}=0.17\right)$ and moderate in stand $1\left(h^{2}=0.24\right)$; it was higher in stand $2\left(h^{2}=0.39\right)$, for the number of roots per cutting (Table 4). The trend was quasi-similar for the length of main root, heritabilities ranging from 0.13 to 0.34 (Table 4). The low or moderate heritabilities are due to the importance of the error component of variance because of a large variation between the cuttings of a same individual (Table 4). This inflates the denominator in the heritability formula and lowers its value. 


\section{Discussion}

\section{Effect of substrate}

It emerged from this work that the type of substrate do not determine significantly differences in frequency of rooting, but exerted an important influence on the quality and vigour of roots of poplar softwood cuttings; gravel, clearly revealed to be superior to sand as regards to the number and length of roots emitted by cuttings.

Studies on the physical properties of the rooting media have not succeed to explain why certain substrates were better than others for rooting (LOACH, 1985; Thompson, 1992). However, one could think that the gravelly substrate, characterised by its greater porosity, allows a better ventilation and drainage of the rooting medium than does the fine sandy substrate, and so favouring multiplication and growth of roots. Such a result is relatively frequent regarding softwood cutting of forest species. For instance, rooting of softwood cuttings in eucalyptus was more intense and of a better quality when the used substrates allowed good ventilation and drainage (CHAPERON and QUILLET, 1977; FAVREAU, 1980). Cuttings of spruce stuck on sand developed fragile and not very ramified root systems (RAUTER, 1983).

\section{Effect of the source of cuttings}

Our findings suggest that softwood cutting of white poplar would be most efficient if root suckers and/or sticklings are used as cuttings donors; however, cuttings from coppice shoots are not uninteresting. Results in softwood cutting of aspen and aspen hybrids varied with authors; KARLSSON and Holm (2002) concluded that the easiest way to root aspen is to use root suckers, while YU et al., for their part, (2001) claimed that stem cuttings and cuttings from coppice of aspen and aspen hybrids are easy to root.

Root suckers are formations developing from roots, which are the major centre of juvenility of a tree (WRIGHT, 1976); hence their superiority as cuttings donors. Sticklings are complete plants developing from rooted cuttings and set for planting; they can be used advantageously as cuttings donors because they were highly rejuvenated. Such a plant material is useful to revive adult trees difficult to propagate by cutting (Kleinschmit, 1977; Morgan et al., 1980; ChAPERON et al., 1983; RAUTER, 1983, DEKKER-RoBERTSON and KLEINSCHMIT, 1991, MENZIES, 1992).

\section{Effect of the period of collection}

Summer reveals to be the best period to achieve good results in white poplar softwood cutting, as it was found in our experiments. In this period, donor plants, probably, are in optimal physiological conditions for vegetative propagation. HALL et al. (1989), for their part, found that the best time for rooting aspen cuttings (Populus tremula L.) is spring and early summer.

Ours findings are in accordance with most results reported in works in the area of softwood cuttings of forest tree species. In a general review on the woody plants cutting, FAVREAU (1980) claimed that rooting ability of cuttings was generally substantially highest in the peri- od from May to July than in autumn and winter. The more propitious period for softwood cutting may vary with species, but it seems that an optimum exists at the height of summer for most hardwood species (THOMPSON, 1992).

The low rooting ability of cuttings collected in early spring is, maybe, related to a persistence of dormancy effects and a scarcity of carbohydrates substances in stems and leaves. In autumn, dormancy effects begin to take place, with a hormonal balance in favour of inhibiting regulators; in addition, biochemical and histological processes such as lignification and sclerenchyme proliferation around the end of the growing season would act to reducing rooting ability of cuttings.

\section{Effect of hormonal treatment}

IBA treatments seemed to have little effect on the rooting response of white poplar softwood cuttings in the present work. Rooting percent and length of roots, more particularly, were not clearly enhanced by the hormonal treatments. The only positive effect of such treatments was an improvement of the number of roots emitted per cutting, suggesting that IBA treatments induce root primordia initiation, but act little on their development. In previous experiments, it has been found, however, that applications of auxin on the base of hardwood cuttings of white poplar were successful to a large extent (BessaFA, 1991).

Earlier findings showed that auxins would act on preexisting root primordia, accelerating their development, but would have no role in the initiation of such formations (HAISSIG, 1974). However, this latter author later reported opposite results in softwood cuttings of Jack pine (Pinus banksiana) (HAISSIG, 1982); the same in the Mediterranean cypress (Cupressus sempervirnes) for which it was observed that the length of the roots was indifferent to hormone stimulator (CAPUANA and LAMBARDI, 1994). In poplars, softwood cuttings of hybrid aspen from micropropagated plants do not need hormonal application to root easily (HAAPALA, 2004).

Results, apparently contradictory or incoherent, often has been reported in the area of hormone treatments in cuttings of forest tree species (RAUTER, 1983; THOMPSON, 1992). It is likely that these regulators do not act independently of several other factors intervening on rooting ability of cuttings, some of them related to the physiological state of cuttings at the time of collection and some others to rooting media and/or genotypes (WILSON and VAN STADEN, 1990). Such interactions between endogenous and exogenous factors make it difficult to postulate general rules in this complex area.

\section{Interaction effects}

Our analyses clearly showed the rooting substrate do not interact with other rooting factors such as the source of cuttings, the period of collection and IBA treatments in white poplar softwood cutting. One could think that the apparent independence between the substrate and the other factors would be due to the chemical inertia of the substrates, i. e. sand and gravel, used in the investigations. 
On the other hand, interactions between the source of cuttings, the period of collection and IBA treatments occurred, specially regarding the intensity of rooting (the number of roots/cutting). Hence, the behaviour of cuttings of a certain source would depend on the period of collection, certain period being more propitious than others for softwood cutting white poplar. The efficiency of different IBA treatments also depends on the period of collecting cuttings and their source; low concentrations IBA would work better with certain types of cuttings collected in certain period, while higher IBA concentrations would be more conclusive in other circumstances.

The occurrence of such interaction effects between factors could be closely related to the endogenous hormonal balance and the amount of carbohydrates in the cuttings and the donor plant, as it was suggested for many forest species (RAUTER, 1983; WILSON and VAN STADEN, 1990; Thompson, 1992; ZALesny et al., 2003).

\section{Effect of stand and individual within stand}

The findings clearly showed that a strong geographic variation in rooting response of softwood cuttings does exist in white poplar, as suggested by the significant differences observed among stands. Similar results were recorded in white poplar with dormant cuttings (BESSAFA, 1991), and in eucalypts with softwood cuttings (Franclet, 1970; ChAPERon and Quillet, 1977).

Many studies reported a large clonal variation in the rooting ability of softwood cuttings in poplars (SCHIER, 1974; Ying and BAGLeY, 1977; DREeSEN and HARRINGTON, 1999; HAAPALA, 2004). Also, in our study, individuals-within-stands ability to produce viable cuttings varied significantly, and revealed a major effect to be taken into account for propagating white poplar by softwood cutting. However, the low or moderate broad sense heritabilities found in this work suggest that microsite effects, at the individual scale, could significantly influence the response to cutting of an individual (clone). Hence; such a response would not to be taken for pure genotypic effects, but rather as combined effects of genotype and periphysis, i.e., the microsite differences within that individual (exposition, light/shadow, etc.) (ZOBEL and TAlbert, 1984; StAnkova and PANETsos, 1997).

Overall, the results of these investigations suggest that selection of stands and, above all, of individuals within stands with good rooting ability, together with taking care with respect to factors such as the period of cuttings collection and the sources of cuttings, could achieve real progress in vegetative propagation of white poplar in Algeria. Moreover, some other factors such as light intensity, root temperature, leaf amount on cuttings, fungicides (KLASs et al., 1986) are likely to play a significant role in the response of clones and thus deserve to be investigated in the future.

\section{References}

ABD-EL-DAYEM, A. M. (2000): Evaluation and genetic identification of some Populus species by using polyacrylamide gel electrophoresis separation of total soluble proteins. In: Poplar and willow culture: meeting the needs of society and the environment. $21^{\text {st }}$ session of the International Poplar Commission (IPC 2000), Isebrands J. G. \& Richardson J Compilers. pp. 1.

Bessafa, B. (1991): Recherches sur l'amélioration des techniques de multiplication végétative du peuplier blanc (Populus alba L.). Magistère thesis National Agronomic Institute, El Harrach, Algiers, 179 pp.

CAPUANA, M. and M. LAMBARDI (1994): Cutting propagation of common cypress (Cupressus sempervirens L.). New Forests 9(2): 11-13.

Chaperon, H. and G. Quillet (1977): Résultats des travaux sur le bouturage des eucalyptus au Congo-Brazzaville. Ed. CTFT Congo, 88 pp.

Chaperon, H., M. Berger, J. Y. Fraysse and D. Leze (1983): Influence de la qualité du pied-mère sur le bouturage des eucalyptus. Annales AFOCEL 1983: 28-53.

DekKeR-Robertson, D. L. and J. Kleinschmit (1991): Serial propagation in Norway spruce (Picea abies (L.) Karst.): Results from later propagation cycles. Silvae Genetica 40: 202-214.

DreEsen, D. R. and J. T. HARRINGTON (1999): Vegetative propagation of aspen, narrowleaf cottonwood, and riparian trees and shrubs. In National proceedings: Forest and nursery conservation associations. General Technical Report SRS-25. USDA Forst Service, Southern Research Station, pp. 129-137.

FAVREAU, J. (1980): Aspects pratiques de multiplication des ligneux par bouturage sous abri. INA Paris, Ed. Bordas, pp. 259-277.

FrAnClet, A. (1970): Technique de bouturage de l'eucalyptus camaldulensis. Note technique, FAO, $51 \mathrm{pp}$.

HAAPALA, T. (2004): Establishment and use of juvenility for propagation in sterile and non-sterile conditions. Academic dissertation, University of Helsinki, Dept of Applied Biology, Publication $\mathrm{N}^{\circ}$ 21, 53 pp.

HAISSIG, B. E. (1974): Influence of auxin and auxin synergists on adventitious root primordium initiation and development. New Zeal. J. For. Sci. 4: 311-323.

HAIssig, B. E. (1982): Influence of aryl esters of indole-3acetic abd indole-3-butyric acids on adventitious primordium initiation and development. Physiol. Plant. 47: 29-33.

Hall, R. B., J. P. Colletti, R. C. Schultz, R. R. FaltonsON, S. H. Kolison JR., R. D. Hanna, T. D. Hillson and J. W. MorRISON (1989): Commercial-scale vegetative propagation of aspen. In the proceedings of aspen symposium 25-27 July, Duluth MN., pp. 211-219.

Hartmann, H. T., D. E. Kester, F. T. Davies JR. and R. L. GENEVE (1997): Plant propagation: principles practices. $6^{\text {th }}$ ed. Prentice-Hall of India Private Limited, New Delhi, pp. 1-770.

Husen, A. and M. PAL (2003c): Clonal propagation of Teak (Tectona grandis Linn. f.): effect of IBA application and adventitious root regeneration on vertically split cuttings. Silvae Genetica 52 (3-4): 173-176.

Husen, A. (2004): Clonal propagation of Dalbergia sissoo Roxb. By softwood nodal cuttings: Effects of genotypes, Application of IBA and Position of cuttings on shoots. Silvae Genetica 53 (2): 50-55.

KARLSSON, K. and S. Holm (2002): Industrial aspen plantations in Finland. In: PulkKinen, P., Tigerstedt, P. M. A. and ViIRros, R. (eds.). Aspen in papermaking. University of Helsinki, Department of Applied Biology, Publication $\mathrm{n}^{\circ} 5$. 
KLASS, S., J. WRIGHT and P. FELKER (1986): Influence of Auxins, thiamine, and fungal drenches on the rooting of Prosopis alba clone $\mathrm{B}_{2} \mathrm{~V}_{50}$ cuttings. Journal of Horticultural Science 60: 97-100.

KLeinschmit, J. (1977): Problems of vegetative propagation. In: $3^{\text {rd }}$ World Conf. For. Tree Breeding, Fo-FTB-774/5, Sweden, part two, pp. 783-798.

LOACH, K. (1985): Rooting of cuttings in relation to the propagation medium. Int. Plant Prop. 35: 472-485.

MenzIES (1992): Management of stock plants for the production of cutting material. In the proceedings of the 1992-symposium of Bordeaux: Mass production technology for genetically improved fast growing forest tree species. Ed. AFOCEL, 257-270.

Morgan, D. L., E. L. Mc Williams and W. C. Parr (1980): Maintaining juvenility in live oak. Hort. Sci. 15: 493-494.

RICHARDSON, J. (1998): Industrial potential of poplars in Canada. In the Proceedings of the 1998-annual meeting of the Poplar Council of Canada: "Getting ready for the $3^{\text {rd }}$ millenium", pp. 13-23.

RAUTER, R. M. (1983): Current status of macropropagation. In: Clonal forestry: its impact on tree improvement and our future forests. Proceedings of the $9^{\text {th }}$ meeting of CTIA, Toronto, part 2. pp 58-74.

SchIER, G. A. (1974): Vegetative propagation of aspen: Clonal differences in suckering from root cutting and in rooting of sucker cutting. Can. J. For. Res. 4: 565-567.
Stankova, T. and K. PAnetsos (1997): Vegetative propagation of Cupressus sempervirens L. of Cretan origin by softwood stem cuttings. Silvae Genetica 46(2-3): $137-144$

Thompson, D. G. (1992): Current state-of-the-art of rooting cuttings and a view to the future. In the proceedings of the 1992-symposium of Bordeaux: Mass production technology for genetically improved fast growing forest tree species. Ed. AFOCEL, 333-349.

Wilson, P. J. and J. VAN STADEN (1990): Rhizocaline, rooting co-factors, and the concept of promoters and inhibitors of adventitious rooting- A review. Ann. Bot. 66: $479-490$.

WRIGHT, J. W. (1976): Introduction to Forest Genetics. Academic Press, New York, 463 pp.

YING, CH. CH. and W. T. BAgLey (1977): Variation in rooting capability of Populus deltoides. Silvae Genetica 26(5-6): 204-207.

Yu, Q., P. M. A. Tigerstedt and M. HaApanen (2001): Growth and phenology of hybrid aspen clones (Populus tremula L. x Populus tremuloides Michx.). Silva fennica 35(1): 15-25.

Zalesny, R. S., Jr., R. B. Hall, E. O. Bauer and D. E. RIEMENSCHNEIDER (2003): Shoot position affects root initiation and growth of dormant unrooted cuttings of Populus. Silvae Genetica 52(8-6): 273-279.

ZoBel, B. and J. TALBERT (1984): Applied forest tree improvement. John Wiley and Sons Inc., New York, USA, 505 pp.

\title{
Variability of Cortex Terpene Composition in Cupressus sempervirens $\mathrm{L}$. provenances grown in Crete, Greece
}

\author{
By A. T. Gallis ${ }^{1)}$, A. G. Doulis ${ }^{2)}$ and A. C. Papageorgiou ${ }^{3)}$
}

(Received 23 $3^{\text {th }}$ September 2006)

\begin{abstract}
The terpene composition of twigs in 106 trees from 6 provenances of Cupressus sempervirens L. grown in the island Crete of Greece was determined by GLC-MS analysis. The aim was to investigate the utility of cortex terpene composition to study the genetic variation between cypress provenances. Twenty nine compounds were detected in cortex resin of all trees, twenty one of

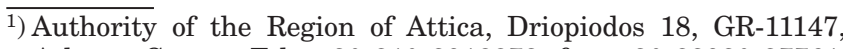
Athens, Greece, Tel.: +30 210 2918873, fax: +30 2292027761 . E-mail: tgallis@hotmail.com.

2) Laboratory of Plant Biotechnology, Institute of Viticulture, Floriculture and Vegetable Crops. National Agricultural Research Foundation of Greece (NAGREF) P.O. Box 2229, GR-71003, Heraklion, Greece. Tel.: +30 2810 242870, fax: +30 2810 245873. E-mail: andreas.doulis@nagref-her.gr.

3) Department of Forestry, Environment and Natural Resources, Democritus University of Thrace, P.O. Box 129, Pantazidou 193, GR-68200, Orestiada, Greece. Tel.: +30 25520 41155, fax: +30 25520 41192. E-mail: apapapge@fmenr.duth.g‥
\end{abstract}

which identified. The major constituents were cedrol, $\alpha$-pinene, 3 - $\delta$-carene and $\alpha$-terpinyl acetate. A cluster analysis based on the amounts of the four evaluated compounds classified all the trees in five chemotypes. The chemotype pattern for every provenance was determined. Based on distribution of chemotypes two main groups of provenances can be suggested.

Key words: Cupressus sempervirens L., Cupressaceae, cortex terpene composition, provenance variability, GLC-MS, Crete, Greece.

\section{Introduction}

In the Mediterranean region, Cupressus sempervirens L. is a very important forest tree species for multiple purposes in forestry because of its ability to grow in adverse environments such as calcareous, clayish, dry and poor soils (XENOPOULOS et al., 1990). Through the geographical distribution the Mediterranean or Italian or common cypress comprises two main morphs: a) 